\title{
Prevalence and Intensity of Nematode Infection on The Crossbreed Horse in Detasemen Kaveleri Berkuda Parongpong Bandung West Java
}

\section{Prevalensi dan Intensitas Infeksi Nematoda pada Persilangan Kuda di Pasukan Berkuda Parongpong Bandung Jawa Barat}

\author{
${ }^{1)}$ Sesa Puput Febriyanti, ${ }^{2}$ Lucia Tri Suwanti, ${ }^{3}$ Eka Pramyrtha Hestinah, ${ }^{2)}$ Setiawan Koesdarto, \\ ${ }^{4)}$ Boedi Setiawan, ${ }^{2}$ Kusnoto \\ ${ }^{1)}$ Student, Faculty of Veterinary Medicine, Universitas Airlangga \\ ${ }^{2)}$ Department of Veterinary Parasitology, Faculty of Veterinary Medicine, Universitas Airlangga \\ ${ }^{3)}$ Department of Veterinary Anatomy, Faculty of Veterinary Medicine, Universitas Airlangga \\ 4)Department of Veterinary Clinic, Faculty of Veterinary Medicine, Universitas Airlangga. \\ Received: 25-02-2019, Accepted: 10-03-2019, Published Online: 19-03-2019
}

\begin{abstract}
This survey study was aimed to determine the prevalance of nematodosis and intensity on the Crossbreed Horse in Detasemen Kaveleri Berkuda Parongpong Bandung West Java. The benefits of this research are to contribute giving additional information about Prevalence, Intensity, and Relation among prevalance with age, sex, and stable. Fecal samples were tested by native, sedimentation, and floatation methods. The examination was found some kind of worm eggs, which are: Trychonema sp., Strongylus spp., Dictyocaulus arnfieldi (lung worm). The result showed that the prevalence of nematodosis was $12.03 \%$. in the calculation of worm eggs per gram feces of Crossbreed Horse in Detasemen Kaveleri Berkuda that have relatively moderate infection were $1123 \mathrm{EPG}$ and result analyze with ANOVA showed no real different with function of horse. The result of statistical analysis using Chi-Square test showed no significant differences in prevalence with age and sex ( $>>0.05)$. the result of statistical using Chi-Square test showed significant differences in prevalence with stable in Detasemen Kaveleri Berkuda ( $<<0.05)$.
\end{abstract}

Keyword : prevalence, intensity, nematodosis, crossbreed horse

\section{Introduction}

Horse cavalry detachment is one of the Tentara Nasional Indonesia functional units operating in the field of defense security with horse animals as one of the key areas. The horses in Denkavkud at most are state-owned horses that require good performance. Helminthiasis can decrease horse performance. Most cases of helminthiasis are from gastrointestinal Nematode (Kachhawa, 2015). The reason is the gastrointestinal tract provides an environment suitable for the survival and proliferation of many parasites (Umar et al., 2013). Record of horse health about nematode parasite infection in Denkavkud has not been done and until now there has been no research on the case of nematodosis in Denkavkud.

The impact of gastro intestinal nematode worm infection is variated, such as decreased work productivity because it can cause weakness, loss of body weight, colic, decreased appetite, diarrhea and even death (Levine, 1994). Worm infections may be affected by poor sanitation and environmental conditions (Andrade et al., 2001). One of the factors that influence nematodosis is age, young age is more susceptible to worm infections because they do not have their own immunity (Koesdarto et al., 2007).

Commonly nematode worms found in the horse's gastrointestinal tract are S.vulgaris, $S$. equinus, S. edentatus, Parascaris equorum, $S$. westeri, Trichostrongylus axei, and Oxyuris equi (Soulsby, 1986). According to research (Boxell et al., 2004) most horses in Perth, Australia are infected with nematode worms. Ulu and Guclu (2007) reported that Strongylus spp infection is the most commonly found in horses whereas infection with Habronema spp. is the least discovered.

The Crossbreed Horse population in Denkavkud is $\mathbf{2 4 2}$ horses. The Crossbreed Horses there are required to be healthy because it is often used for state occasions and following the race. Parasitic infection, especially helminthiasis in the horse's digestive tract, is a major 
factor that can harm the health of horses because a healthy horse appears to be infected with more than half a million gastrointestinal parasites (Stoltenow and Purdy, 2003; Martins et al., 2009). Therefore even though the horses in Denkavkud look healthy and have been given Ivermectin and Fenbendazole under the trademark as Penacur anthelmintic routine 3 months once need to be examined the prevalence of worm infection because some worms have resistance. According to Molento research (2008) the Strongylus equinus worms are resistant to Ivermectin and Fenbendazole but both anthelmintics are highly effective in treating infections caused by Parascaris equorum. To determine the degree of infection is done calculation of Eggs Worms Per Gram Feces (EPG) (Soulsby, 1986). This was in accordance with the number of eggs according to Nofyan et al., (2010) in mild infections, worm eggs 1-49oEPG were found, in moderate infection worm eggs 500-500oEPG were found, and in severe infection worm eggs were found to be more than 5000 EPG.

\section{Research Method}

In this research, feces were collected in Horse Cavalry Detachment (Denkavkud) TNIAD Bandung and examination of feces in Laboratory of Parasitology of Veterinary Medicine of Universitas Airlangga Surabaya. The materials used in this study were fresh horse stools that were fed formalin $10 \%$, saturated $\mathrm{NaCl}$, aquades, and ice cubes. The tools used in this research were cool box, plastic clip, plastic spoon, labeling, measuring cup, dropper/paste pipes, strainer, glass object, glass cover, gauze, centrifuge tube, digital analytics scales, gloves, mask, centrifugation and microscopy. Feces as sample were collected in the morning at the stables. Fresh feces from the gastrointestinal tract are taken with a spatula, then inserted into a closed plastic container and then given $10 \%$ formalin, after which it was labeled for horse identity, sex, and age. The collected stool samples were further examined at the Parasitology Laboratory of Faculty of Veterinary Medicine Univer.

To determine the presence of worm eggs in the sample, the examination was examined by using native method (simple), sedimentation method, and floating method. Native method has procedure such as, took a little stool by using a small stirrer tip and then smeared on the object glass. Added a drop of water and flatten it, covered it with a glass cover. Then examined under a microscope with 10ox magnification (Mumpuni et al., 2017).

Sedimentation method was feces were put into plastic cups then added water with a ratio of 1:10. Feces and water are stirred until blended and then filtered, the filter results are inserted into the centrifuge tube then centrifuged for 25 minutes at $1500 \mathrm{rpm}$. The supernatant was removed, while the precipitate is added water again as the previous step is then centrifuged for 2-5 minutes at $1500 \mathrm{rpm}$. This process was repeated until the supernatant was clear. After cleansing, the supernatant was removed and left slightly, the precipitate stirred and taken slightly with a Pasteur pipette then placed in a glass cover object with a glass cover and examined under a microscope with 10ox magnification (Mumpuni et al., 2017). Floating method was feces were put into plastic cups then added water with a ratio of 1:10. Feces and water were stirred until blended and then filtered, the result of the filter inserted into the centrifuge tube then centrifuged for 2-5 minutes at a speed of $1500 \mathrm{rpm}$. The supernatant was removed, the precipitate added water again as the previous step then centrifuged again for 2-5 minutes at $1500 \mathrm{rpm}$. This process was repeated until the supernatant was clear. Once clear, the supernatant was removed and left slightly, added a saturated sugar solution of up to $1 \mathrm{~cm}$ from the mouth of the tube, then centrifuged in the same way. After centrifugation, the centrifugation tube was placed on a tube rack and gradually droped with a saturated sugar solution until the liquid was visible convex to the centrifuge mouth and placed the glass cover on the surface of the centrifuge tube for 5 minutes. The glass cover was lifted and placed on top of the object glass and examined under a microscope with 10ox magnification (Mumpuni et al., 2017).

The positive samples were continued with EPG calculations by Lucient Brumpt method, by five grams of stool diluted with water by a ratio of one to one. Then the suspension is filtered with a tea strainer. The worm egg counting was done by placing one drop of fecal suspension on the object glass, covered with cover glass and then examined under a microscope with 10ox magnification (Mumpuni et al, 2017). The calculation of formula was as follows :

$E P G=N \times n \times K, E P G$ : egg worms per gram of feces, $\mathrm{N}$ : Number of drops in $1 \mathrm{ml}$ of stool suspension, n: Number of eggs counted in 1 drop, K: Dilution coefficient. 


\section{Data Analysis}

When in the examination of positive feces samples found worm eggs then to know the prevalence was calculated using the formula as follows:

$$
\text { Prevalence }=\frac{\text { The number of positive }}{\text { The number of examined }} \times 100
$$

Statistical analysis used Chi Square test and ANOVA using SPSS (Statistical Product and Service Solution) for Windows rel 23.

\section{Result and Discussion \\ Prevalance Nematode Infection on the Crossbreed Horse in Detasemen Berkuda Parongpong \\ The results showed from 108 samples, 13} samples were positive with comparative rates of the prevalence $12.03 \%$ of nematodosis (Table 1 ). The calculation results showed that 5 horses had a single infection of Trichonema spp., 3 horses had a single infection Dictyocaulus arnfieldi, and 5 horses had mixed infections. The 108 samples were examined and 13 of them only nematodes worm were found because they had fast cycle (Subekti et al., 2007). The Nematodes were Trichonema spp., Strongylus spp., and Dictyocaulus arnfieldi..

The biggest worm infection in the results of this study was Trichonema spp. infection, better known as Small Strongylus worm 5 single infections, 4 mixed infections with Strongylus spp., and 1 mixed infection with Strongylus spp. and $D$. arnfieldi. Infection of Strongylus spp. always followed by infection of Trichonema spp. (Soulsby, 1986).

The incidence of Trichonema sp. infection had not been studied as much as Large Strongyl. However, there was no evidence that they moved around in the body. The development of free life stages was the same as Big Strongyl (Levine, 1994). Where as Strongylus spp. infection had been occuring even with the lowest prevalence. This happened because the worm medicine given, namely Ivermectin, had experienced resistance to the Strongylus spp. (Wolf, et al., 2014; Molento, 2008). In the Dictyocaulus arnfieldi infection attacked the horses in the 1-year-old horse because this worm infection would occur if the horse was malnourished

The prevalence of horses in Denkavkud was $12.03 \%$, which is lower than the research conducted by Utami (2013) at Batu Secret Zoo which was $33.33 \%$ and in Taman Safari Indonesia II at $37.04 \%$. The low prevalence of nematodosis in Denkavkud was caused by routine administration of worm medicine 3 months used Ivermectin and Fenbendazole to all ages of horses.

Table 1. Prevalance of Nematodosis on The Crossbreed Horse in Denkavkud

\begin{tabular}{lcc}
\hline & \multicolumn{2}{c}{ Prevalence } \\
\cline { 2 - 3 } & Total & $\%$ \\
\hline Positive & 13 & $\mathbf{1 2 . 0 3}$ \\
\hline Negative & 95 & 87.96 \\
\hline Total & 108 & 100
\end{tabular}

The type of worm eggs obtained from Crossbreed horse feces samples are digestive nematode worms, namely Trichonema spp. or often called small Strongyles and Strongylus spp.. Predicted nematodes in the horse's lungs were also found, namely Dictyocaulus arnfieldi. Trichonema spp. eggs were found in 10 samples had average size of 100.101x46.500 $\mu$. Sytongylus spp. found in mixed infections that had average size of $82.230 \times 44.245 \mu \mathrm{m}$. Whereas elliptical $D$. arnfieldi eggs had average size of $90.345 \times 87.520 \mu \mathrm{m}$ which contains worm larvae and protects the horse's lungs.

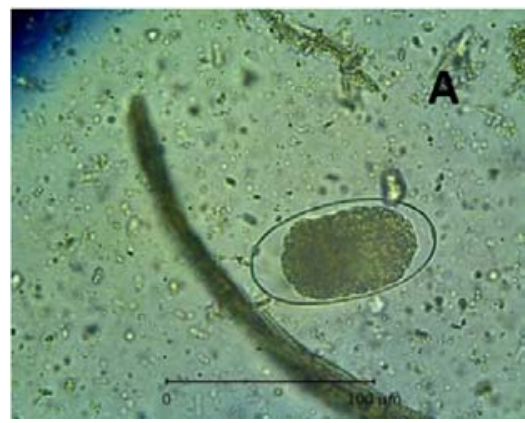

Figure 1. (A) Egg of Trichonema sp. magnification 40ox.

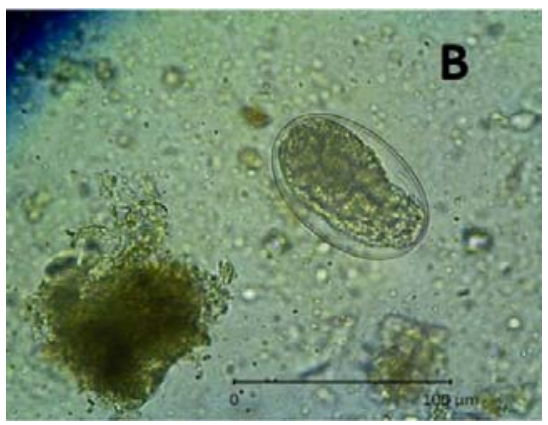

Figure 2. (B) Egg of Strongylus spp. magnification 40ox. 


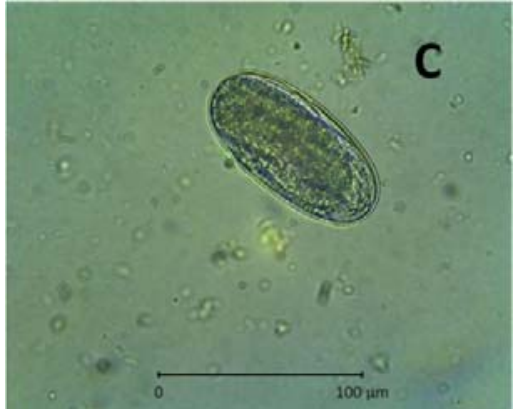

Figure 3. (C) Egg of Dictyocaulus arnfieldi magnification 40ox.

\section{Nematodosis Based on Age The Crossbreed Horse in Denkavkud}

In this calculation it was found that the highest prevalence in young horses with $D$. arnfieldi worm infection and the lowest was the prevalence of old horses infected with $D$. arnfieldi. The results of the Chi-Square analysis of age with prevalence that have no significant differences ( $>0.05)$. But the results of the study by Setiyono (2007) and Sari (2014) state that age affects nematodosis. This differrent result was caused by the animals that were observed differently, which stated that age affecting nematodosis was in beef cattle. In this research the young horse was 1 year old so had own immune whereas 6 months animal had no own immune (Koesdarto, 2007).

\section{Nematodosis Based on Sex The Crossbreed Horse in Denkavkud}

The results of the prevalence calculation mares had more nematode infections than stallions. Infection of Trichonema spp. was the highest and Strongylus spp. was the lowest The Chi-Square test results showed that sex were not significantly different ( $p>0.05)$ on the prevalence of Nematode worms. This showed that both mares and stallion had the same chance in Nematode infection. The results of the Setiawan (2013) and Mahardika (2013) study also state that gender did not affect the occurrence of nematode infections.

Table 2. Prevalance Based on Age

\begin{tabular}{llll}
\hline & $\begin{array}{l}\text { Young }(0- \\
\text { 2 years) }\end{array}$ & $\begin{array}{l}\text { Adult }\left(3^{-}\right. \\
\text {15 years) }\end{array}$ & $\begin{array}{l}\text { Old }(>15 \\
\text { years })\end{array}$ \\
\cline { 2 - 4 } Strongylus & $0.92 \%$ & $1.85 \%$ & $0,92 \%$ \\
spp. & $(1 / 108)$ & $(2 / 108)$ & $(1 / 108)$ \\
Trichonema & $0.92 \%$ & 5.55 & $1.85 \%$ \\
spp & $(1 / 108)$ & $(6 / 108)$ & $(2 / 108)$ \\
Dictyocaulus & $1.85 \%$ & $1.85 \%$ & $0,92 \%$ \\
sp. & $(2 / 108)$ & $(2 / 108)$ & $(1 / 108$ \\
\hline Total & $3.69 \%$ & $9.25 \%$ & $3.69 \%$
\end{tabular}

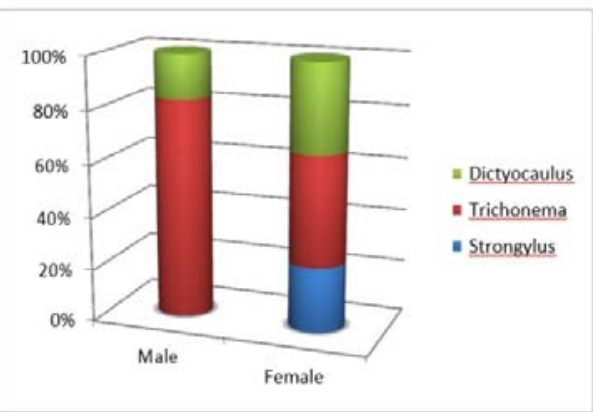

Figure 4. Prevalance Based on Sex.

Nematodosis Based on Stables on The Crossbreed Horse in Denkavkud

The results of the calculation of prevalence based on the distribution of stable indicate that the treatment stable had the highest prevalance rate of $66.67 \%$ with mixed infections of the Trichonema spp., Strongylus spp., and Dictyocaulus arnfieldi. While the other seven cages have no nematodosis infections. The results of the Chi-Square analysis showed that the distribution of horse stable at Denkavkud was significantly different from the occurrence of nematode infection $(\mathrm{p}<0.05)$. The results of Setiawan's (2013) study also stated that the stable affected the incidence of nematodosis. This was due to differences in the location of each stable where the stables $A, B$ and $C$ were located higher than the other stables. Lower stable had different humidity, worms lived and developed well in warmer and humid conditions (Kusumamiharja, 1993).

Table 3. Prevalence Based on Stables

\begin{tabular}{lc}
\hline \multicolumn{1}{c}{ Stable } & Prevalence \\
\hline Riding & $7 / 73(1.89 \%)$ \\
Foal & $3 / 10(30.00 \%)$ \\
Mare & $1 / 26(0.03 \%)$ \\
Treatment & $2 / 3(66.67 \%)$ \\
Breeding & $0 / 32(0.00 \%)$ \\
\hline Total & $13 / 108(12.03 \%)$
\end{tabular}

Intensity of Nematodosis on The Crossbreed Horse in Denkavkud

Based on the calculation of EPG there was a moderate infection with a range of 500-5000 EPG. This was in accordance with the number of eggs according to Nofyan et al., (2010) in mild infections, worm eggs 1-49oEPG were found, in moderate infection worm eggs 5005000 PPG were found, and in severe infection worm eggs were found to be more than $5000 E P G$. 


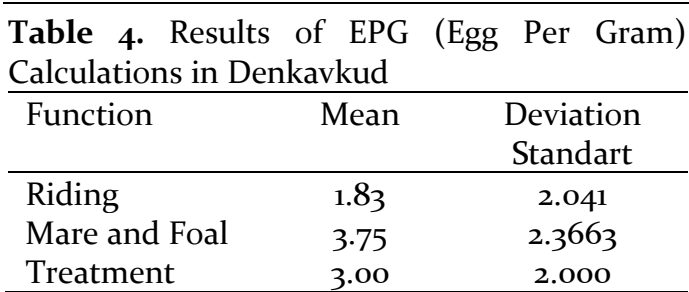

The result of ANOVA test showed that horse function was not related with intensity of infection. Stable A, C, E, G as the riding horse reached the EPG value which included mild infection 20oEPG. This condition happened because each stable had its own stable keeper which had different levels of cleanliness with other stable keeper such as stable $\mathrm{M}$ as mare horse and $\mathrm{J}$ as riding horse whose sanitation was poorly maintained so that the infection rate was moderate to severe. According to Usri (2011) environmental pollution due to accumulated feces made wet and humid conditions so that worms developed in a long time. Stable $\mathrm{L}$ was a young horse that had a moderate infection rate because young horses did not have their own immune system (Koesdarto, 2007). Stable O was a treatment stable that contained horses with symptoms of a particular disease and therapeutic treatment would be carried out so that the horse in stable $\mathrm{O}$ had a moderate infection. Moderate infection occured in the horses at Denkavkud because the anthelmintic that had been given, such as Ivermectin and Fenbendazole had experienced resistance to several types of Nematode worms such as the Small Strongyl group and the Big Strongyl.

\section{Conclusions}

The prevalence of Nematode worms in horses at Denkavkud was $12.37 \%$. Types of worm eggs Nematodes that infected the digestive tract of horses in Denkavkud, such as Trichonema spp. and Strongylus spp. In addition, Nematode worms predisposed to the lungs, Dictyocaulus arnfieldi, were also found. The intensity of Nematode worm infection in horses in Denkavkud was classified as a moderate infection of ${ }_{1123} \mathrm{EPG}$. Sex factor was not significantly different from Nematode worm infections in horses on Denkavkud. Age factor was not significantly different from Nematode worm infection in horses on Denkavkud. The stable factor was significantly different from Nematode infection in horses on Denkavkud.

\section{Refrences}

Andrade, C., T. Alava, and I.A De Palacio .2001.Prevalence and Intensity of Soiltransmitted Helminthiasis in the City of Portoviejo (Ecuador). J. Pub Med. 96(8): 1075-1079.

Boxell, A.C., K.T. Gibson., R.P Hobbs and R.C. Thompson. 2004. Occurrence of Gastrointestinal parasites in horses in metropolitan Perth, Western Australia. J. Aust Vet. 82: 91-95.

Kachhawa, J.P.2015.Epidemiological Studies on Helminthiasis in Horses in Bikaner Region of Rajasthan. Indian Vet. 92 (4) : 100 $-101$.

Koesdarto, S., S. Subekti, S. Mumpuni, H. Puspitawati dan Kusnoto. 2007. Buku Ajar Ilmu Penyakit Nematoda Vetriner. Fakultas Kedokteran Hewan Universitas Airlangga. Surabaya.

Kusumamihadrja, S. 1993. Parasit Dan Parasitosis Pada Hewan Ternak Dan Hewan Piaraan Di Indonesia. Pusat Antar Universitas Bioteknologi, IPB, Bogor.

Levine, N.D., Ashadi, G (Penerjemah). 1994. Buku Pelajaran Parasitologi Veteriner. Second edition. Gadjah Mada University Press. Yogyakarta.

Mahardika, D. 2013. Prevalensi Dan Derajat Infeksi Nematodosis Saluran Pencernaan Pada Pedet Sapi Madura Di Kecamatan Burneh Kabupaten Bangkalan [Skripsi]. Fakultas Kedokteran Hewan. Universitas Airlangga. Hal 33.

Molento, M. B. 2008. Anthelmintic Resistant Nematodes in Brazilian Horses. Laboratório de Doenças Parasitárias, Universidade Federal. 162(12):384-5.

Mumpuni, S., S. Subekti, S. Koesdarto, H. Puspitawati and Kusnoto. 2007. Penuntun Praktikum Ilmu Penyakit Helminth Veteriner. Fakultas Kedokteran Hewan Universitas Airlangga. Surabaya.

Nofyan E, Kamal M, dan Rosdiana I. 2010. Identitas Telur Cacing Parasit Usus Pada Ternak Sapi (Bos sp.) dan Kerbau (Bubalus sp.) Di Rumah Potong Hewan Palembang. Jurusan Biologi FMIPA, Universitas Sriwijaya, Sumatra Selatan.

Sari, I.K. 2014. Prevalensi Dan Derajat Infeksi Cacing Saluran Pencernaan Sapi Peranakan 
Ongole (PO) Dan Limousin Di Kecamatan Tikung Kabupaten Lamongan [Skripsi]. Fakultas Kedokteran Hewan. Universitas Airlangga. Hal 46.

Setiawan, A.E. 2013. Prevalensi Dan Derajat Infeksi Cacing Nematoda Saluran Pencernaan Pada Pedet Sapi Limousin Di Kecamatan Rejoso Kabupaten Nganjuk [Skripsi]. Fakultas Kedokteran Hewan. Universitas Airlangga. Hal 35.

Setiyono, H. 2007. Prevalensi Helmintiasis Pada Saluran Pencernaan Sapi Potong Di Desa Panglungan Krcamatan Wonosalam Kabupaten Jombang [Skripsi]. Fakultas Kedokteran Hewan Universitas Airlangga. Hal 33-34.

Stoltenow, C.L., and Purdy C.H. 2003. Internal parasites of Horses. NDSU Extension Service. North Dakota State University Agr. Appl. Sci. V. 543.
Subekti. S., S. M. Sosiawati, dan Kusnoto. 2007. Ilmu Penyakit Nematoda Veteriner. Departemen Pendidikan dan Kebudayaan. Fakultas Kedokteran Hewan Universitas Airlangga. Surabaya.

Umar YA, Maikaje DB, Garba UM, Alhassan MAF (2013). Prevalence Of Gastrointestinal Parasites In Horses Used For Cadets Training in Nigeria. J. Vet. Adv., 3(2): 43-48. Uslu, U. and F. Guclu. 2007. Bull. Vet. Inst. Pulawy. 51: 237.

Usri N. 2001. Manajemen Peternakan Sapi Potong Seta Kaitannya dengan Pencemaran Lingkungan dan Kesehatan Ternak. Media Kedoteran Hewan. Vol. 1.7. 1-4. 